\title{
Influence of Critical Thinking Technologies on Improvement of Students Performance During Self-Study
}

\author{
Mariia Morozova $^{1, *}$, Larisa Gula ${ }^{2}$, Nataliia Dymar ${ }^{3}$, Inna Diachenko ${ }^{4}$ \& Nataliia Bykadorova ${ }^{5}$ \\ ${ }^{1}$ Department of Commodity Research, Commercial Business and Goods Expertise, The Institute of Trade, Customer \\ Services and Tourism, Luhansk Taras Shevchenko National University, Starobilsk, Ukraine \\ ${ }^{2}$ Department of Vocational Training Methods, Faculty of Engineering and Energy, Mykolayiv National Agrarian \\ University, Mykolayiv, Ukraine \\ ${ }^{3}$ Department of Biology, Faculty for Training of Foreign Citizens, Bogomolets National Medical University, Kyiv, \\ Ukraine \\ ${ }^{4}$ Department of Natural and Social and Humanities Disciplines, Zhytomyr Medical Institute of Zhytomyr Regional \\ Council, Zhytomyr, Ukraine \\ ${ }^{5}$ Department of Production Technology and Professional Education, The Institute of Trade, Customer Services and \\ Tourism, Luhansk Taras Shevchenko National University, Starobilsk, Ukraine
}

*Correspondence: Luhansk Taras Shevchenko National University, 1, Gogol Square, Starobilsk, Luhansk Region, 92703, Ukraine. E-mail: morozovamiam@gmail.com

Received: December 7, 2021

Accepted: January 6, 2022 Online Published: January 17, 2022

doi:10.5430/jct.v11n1p59

URL: https://doi.org/10.5430/jct.v11n1p59

\begin{abstract}
Applicability of the article is preconditioned by the requirements of information-oriented society that dictate modern youth the necessity of work with information ability, to see, to envisage and to correct logic errors. In modern world it is important to conduct reflection of own activity that maintain the necessity of critical thinking development, especially during individual acquisition of knowledge by students of higher educational establishments. Though critical thinking is introduced at school, it should be developed actively also on the next levels of education, including the level of higher education. Aims. To check complex of methods of critical thinking methods directed to the development of intellectual educational skills of students during unsupervised work. Methods: general scientific methods of information analysis were used in the research. Questionnaire method was introduced with the help of methods of the level of competency certification of Yu. Tatur, "critical analysis" of Barret, finding of logical errors of Cheifits. Qualimetric approach of the research of level of competency certification. Semantic differential tear of J. Dease. Statistic analysis was performed with the help of Spearman's rank correlation coefficient. Results. During the research it was revealed that the average rate of rational thinking of all groups of respondents is on the average level and is equal to about $50 \%$. Propensity for sweeping generalizations of students of $1-2$ years of study is $10 \%$ higher, students of 2-3 years of study is for $10 \%$ more empiric one. Empiric objectness of students of 3-4 years of study is $14,5 \%$, and students of $1-2$ years of study is from $11,4 \%$ to $12,1 \%$. Conclusions. According to all criteria of diagnostics of efficiency of critical thinking effect on self-guided work if students positive dynamics was revealed. Students of 1-2 years of study showed higher potential for self-guided work than students of 3-4 years of study. Perspectives. Further researches can be organized in direction of development and introduction of critical thinking development for improvement of acquirement of competences with regard of future professional activity.
\end{abstract}

Keywords: critical thinking, development of intellect, self-guided work, organization of work, improvement of successfulness

\section{Introduction}

Thematic justification is conditioned by the fact that in addition to acquirement of specific knowledge the stable formation of intellectual educational skills comes to the fore. These skills mastering determines the effectiveness of solution of new knowledge problem and their further application in the process of transforming activity. We can attribute as such knowledge the classification, systematization, abstraction, generalization of material with further 
formulation of conclusions, identification of patterns (Akramova \& Akramova, 2021; Savchenko \& Kurylo, 2019).

Ability of critical thinking during educational activity of students is inseparably connected with intellectual development. Intellect is defined as systemic form of organization of consciousness. It is the systemic phenomenon that includes the number of functional subsystems and structural functional groups that create fundamental integrity and unity of consciousness. Intellect is the personal formation conveyed in semantic space, so it is not resulted only in abilities or other parts if its structure. Reductions to abilities are wrongful because abilities are only the mechanisms and competencies are only the potencies. Instead of this intellect does not function without the base (sides of mind and cognitive processes), without cognitive formations of mind, namely knowledge, and regulative subsystems, namely cognitive experience. Knowledge are the content of consciousness, so intellect depends on cognitive formations, competencies, structures of mental experience and intellectual "controls". The higher levels of intellect are connected by values, creeds, ideals, world outlooks, higher educations of knowledge and belief. Synthesis of these attributes is attached to personal intellect (Anugraheni, 2017; Marynchenko \& Motsak, 2021).

Analysis of scientific literature showed that now there is rather complete grounding of the problem if formation of intellectual skills of students within the process of educational activity. However, mastering of strategies of study is the necessary condition of ability to develop the professional competencies formation. Technology of students' critical thinking development was developed and grounded on the sufficient level. In addition the necessity to ground and to prove the possibility of use of critical thinking development methods for improvement of progress in students' study (Kobzyeva, 2021; Sujito et al., 2019).

Critical thinking is the check of offered solutions with the purpose of determination of the sphere of their possible application. Creative thinking is directed to creation of new ideas, and critical thinking reveals their disadvantages and defects. Critical thinking differs with control ability, groundness and sense of purpose. Critical thinking is inextricably linked with logic one, because it provides for formation of conclusions, creation of the logical models concerted inter se and acceptance of reasonable decisions. The critical thinking provides for estimation that can and must have structurally positive and negatively relational expression. At the critical thinking not only a result but also mental process, namely chain of arguments that resulted in new conclusions is estimated. The critical thinking is sent to the receipt of result, that is why it is sometimes called directed. A reflection is inalienable part of the critical thinking. In the process of reflection information becomes appropriated, it means that it becomes the own knowledge (Kusumawati et al., 2019; Proshkin et al., 2018). The levels of formation of the critical thinking are presented in a Table 1.

Table 1. Levels of Critical Thinking Formation

\section{LEVEL INDICATOR}

Insufficient Insufficient Characterized by lack of knowledge about critical thinking. Students do not know how to make hypotheses, it is difficult to formulate conclusions without emphasizing of the main and the secondary. They accept everything as the truth, cannot take part in the search for compromise solutions, have difficulties in finding logic errors, are not independent in their judgments, have difficulty in planning activities, have difficulties in reflecting on the activities of both themselves and others.

Basic Students are not influenced by other people's opinions, able to see the strengths and weaknesses of the situation, separate the main and secondary problems, able to see the logical connections between actions or phenomena, able to plan, but can make errors in the sequence of actions, compromise is allowed only after argumentation. It is not always possible to consider the situation from different positions, the forecast is made, but with insufficient argumentation.

Advanced Possess flexibility and independence of thinking, consider problems from different points of view, fully analyze the problems, offer compromise solutions to problem situations, anticipate and identify logical errors.

Source: compiled by the authors

Among the personal qualities it is important to form in students the abilities and skills to acquire knowledge from various sources, to analyze and systematize the information obtained. The formation of such a skill occurs throughout the study period with the participation of students in practical classes. Such activities directly depend on the development of students' self-education skills, so achieving the required level of qualification is largely determined by increasing the role of independent student work (VTS). Only with this approach it becomes possible to train a specialist who has his own profession and is able to work effectively. All this allowed to identify as the 
main tasks of education such problems as:

- development of students' self-education skills;

- intensification and individualization of training;

- development of a modern structure of academic disciplines;

- introduction of modern information technologies in the educational space of ZVO.

With such a variety of tasks, the basis for improving the quality of training can be the optimization of pedagogical management of cognitive activity of university students in general, and independent activities in particular. As a result, independent learning allows you to create a basis for continuing education, gives students the opportunity to constantly improve their skills, to be socially and professionally mobile person (Sulisworo \& Syarif, 2018; Volet et al., 2019; Weinberger \& Shonfeld, 2018). Methodological approaches to the organization of independent work of students are presented in Table 2.

Table 2. Methodological Approaches to the Organization of Independent Work of Students

\begin{tabular}{|c|c|c|c|c|c|c|}
\hline Subject-activity & \multicolumn{3}{|c|}{ Competence } & \multicolumn{3}{|c|}{ Resource } \\
\hline \multicolumn{7}{|l|}{ Principles: } \\
\hline Resources & Subjectivity & $\begin{array}{l}\text { Professional } \\
\text { orientation }\end{array}$ & Discreteness & Cyclycity & $\begin{array}{l}\text { Projection } \\
\text { transfer }\end{array}$ & $\begin{array}{l}\text { Optimal } \\
\text { intensity }\end{array}$ \\
\hline \multicolumn{7}{|l|}{ Organizational and pedagogical conditions: } \\
\hline $\begin{array}{l}\text { Development and implementation of } \\
\text { a set of tasks of increased complexity, } \\
\text { the solution of which is aimed at } \\
\text { developing the readiness of students } \\
\text { for the future professional sphere and } \\
\text { related fields of activity }\end{array}$ & \multicolumn{3}{|c|}{$\begin{array}{l}\text { Activation of the student's subjective position } \\
\text { on independent decision-making through the } \\
\text { systematic use of active and interactive forms } \\
\text { of learning, e-Learning }\end{array}$} & \multicolumn{3}{|c|}{$\begin{array}{l}\text { Functioning in } \mathrm{ZVO} \text { of the open } \\
\text { educational and resource environment } \\
\text { which is a relevant reflection of } \\
\text { existing features of an information } \\
\text { society and industrial and social and } \\
\text { personal relations consisting in it }\end{array}$} \\
\hline
\end{tabular}

Source: compiled by the authors

Independent work as a means of organizing educational or scientific knowledge of the student has a dual quality. On the one hand, it is a learning task, ie the object of student activity, proposed by the teacher or manual, and on the other hand it is a form of manifestation of a certain method of activity to perform the corresponding educational task. In this regard, the interest in independent work of students in recent years is growing in the scientific and pedagogical literature actively, which clarifies the theoretical aspects, summarizes practical experience, studies the budget of students, ways of rational organization and culture of mental work. Thus, the relevance of this work is due to the need to identify and justify the practical use of techniques for the development of critical thinking, which contribute to the development of intellectual skills of students (Shah \& Lewis, 2019; Romanova, 2021).

The purpose of study: to test a set of techniques for the development of critical thinking, aimed at developing students' intellectual learning skills during independent work experimentally.

To achieve this goal in the study consistently 6 solves the following tasks:

1. Identify and analyze the degree of development of critical thinking of respondents.

2. Identify patterns between the development of critical thinking of respondents and the degree of quality of independent work.

\section{Literature Review}

Many domestic and foreign works are devoted to the study of the peculiarities of students' independent work and critical thinking. From the point of view of socialization in the modern world, critical thinking is considered in the article of Savchenko and Kurilo (2019). The authors note the great importance of critical thinking in the formation of professional communicative competencies of students. Their direct formation as specialists in their field is associated with the development of the ability to think rationally. Foreign experience of using critical thinking as a personality formation of a future specialist is studied in the article by Kozubovska and Povidaychyk (2021). The authors compare domestic and foreign experience of the formation of critical thinking competencies in students of different 
fields of study. Also foreign experience in the formation of critical thinking and its impact on the educational process is studied in the works of Marynchenko and Motsak (2021), Schmitt and Lancaster (2019), Li (2016), Riany et al. (2018). Features of the formation of professional competencies in new generation of students are studied in the works of Hampton and Keys (2017), Seemiller ang Grace (2017).

The authors emphasize in their research the critical need to reform educational methods that would be acceptable for students of the information revolution generation. The research notes the low efficiency of traditional methods of education and proposes a comprehensive integration of IT technologies into the educational process (Panasiuk et al., 2021). The combination of active and interactive methods of education, according to the authors, will help to form the necessary level of critical thinking in students. Osadchyy's (2015) work is devoted to the issue of continuity of education.

The author addresses the issues of improving the skills of independent work in postgraduate education. The impact of the COVID-19 pandemic on the organization of the educational process is discussed in Marshall and Wolanskyj-Spinner (2020), Witriyahati et al. (2021).

Thus, after studying the scientific literature on the topic, we can identify the following series of contradictions:

- scientific and theoretical nature: between the need for theoretical understanding of the problem of development of critical thinking of students and insufficient scientific and theoretical development of ways to develop it in the process of independent work;

- scientific and methodological nature: between the recognition of the importance of the development of critical thinking in students and the insufficient development of methodological and technological aspects of such activities.

\section{Methods}

\subsection{Research Design}

Research Design

The experimental work took place in three stages.

I stage of the experiment (September 2020 - January 2021) - ascertaining. Experimental work at this stage included:

- study of pedagogical conditions of formation of critical thinking in students;

- analysis of factors that can improve the success of students' independent work;

- preparation for the study.

II stage of the pedagogical experiment (January - May 2021) - formative.

At the formative stage, the content of the experimental work included:

- introduction of pedagogical conditions to improve the success of students in independent work through the development of critical thinking;

- control over the course of the pedagogical experiment with the help of questionnaires;

- analysis and processing of the results obtained during the experiment;

- summarizing the results of the pedagogical experiment.

Stage III of the pedagogical experiment (June - September 2021) - final. The content of this stage of the experiment included systematization and generalization of the results of experimental work, formulation of research conclusions.

\subsection{Sample}

General totality is limited to students of management specialties. The sample is serial, simplified in structure, norms and volume of representativeness, in the range of surveyed categories of student youth and is 200 respondents. This corresponds to the norms of the intelligence plan and the goals of empirical confirmation: the system theory of intelligence and the construction of a typology of intellectual deviations. Units of the series - student groups (20-25 people), grouped by study groups. Monitoring of students' motivation to study during the study of the effectiveness of modeling of educational and professional training of students was carried out on the basis of the National Pedagogical University named after MP Drahomanov (Kyiv). The study involved students of 1-4 courses of the Faculty of Engineering and Pedagogy and the Faculty of Education and Science Management. 


\subsection{Methods}

1. Qualimetric approach to the study of the level of formation of competencies. The essence of the qualimetric approach is to provide pedagogical measurements with reliable tools for multi-criteria evaluation of indicators of the educational process and educational outcomes. Establishment of a data bank for making adequate management decisions to manage the quality of the educational process and its results. Given the multidimensionality of the educational process, quantitative assessment of the quality of education is one of the most complex and least developed problems. The main difficulties in implementation of qualimetric approach in the practice of pedagogical activities are related to the complexity of developing tools, overcoming of the formal nature of obtaining statistical information, which is limited by the number of excellent and unsuccessful.

2. The following testing methods were used in the study:

- Methodology of the level of formation of competencies Yu. Tatura. Competence contains three components: gnostic, which characterizes the quality of knowledge as the basis of competencies; functional, which determines the ability; value-ethical, which characterizes the attitude to activity. Taxonomic tables (Appendix A) that describe the levels of development of competence components were developed.

- method of semantic differential, developed by J. Diz.

- Methods of "critical analysis" by J. Barrett.

- Methods of finding logical errors of Michael Chaifitz.

Each technique was a task. Respondents recorded the answers in the form online.

As a result, structured headings of the form were obtained. The main method of researching of the respondents' answers was content analysis.

3. The development of competence potential (PKC) can be determined by adding the sum of points for the gnostic and functional components, ie:

$$
\mathrm{PKC}=\mathrm{C}+\mathrm{B}
$$

where $\mathrm{C}$ is the total score for the "Knowledge" component;

B - total score for the "Skills" component.

4. Spearman's rank correlation coefficient is calculated according to the formula:

For random variables $\mathrm{X}$ and $\mathrm{Y}$, the formula for calculating the coefficient $\rho$ is as follows:

$$
\mathrm{P}=\frac{6 * \Sigma\left(D^{2}\right)}{n *\left(n^{2}-1\right)}
$$

where $\mathrm{C}$ is the total score for the component "Knowledge";

B - total score for the component "Skills".

4. Spearman's rank of correlation coefficient is calculated according to the formula:

For random variables $\mathrm{X}$ and $\mathrm{Y}$, the formula for calculating the coefficient $\rho$ is as follows:

\subsection{Tools}

Google Forms features were used for the survey. Data entry and processing was performed using the software product "Microsoft Excel" and "SPSS Statistics 21.0". All data are given in relative (\% of the number of respondents) values.

\section{Results}

Assessments are performed on graduated bipolar scales (3-7 points), with dichotomous assessment categories. Stimulus material is a set of images: art paintings and abstract symbols. Some respondents singled out only the main elements, omitting the secondary ones, some compared the main elements with the secondary ones, some gave the secondary elements decisive importance and ignored the main elements.

Priority features are semantic nodes that delineate the boundaries of the frame. Secondary elements are a condition for understanding the priority features and participate in the general conceptual and figurative gestalt. The average level of rationality in all categories of respondents is about $50 \%$ (Table 3 ). 
Table 3. Analysis by Frames (in\%)

\begin{tabular}{lccccc}
\hline \multirow{2}{*}{ Courses } & The difference in amounts & \multicolumn{2}{c}{ Rational idea } & \multicolumn{2}{c}{ Irrational idea } \\
\cline { 2 - 5 } & $\Sigma_{\text {rac }}-\Sigma_{\text {irrac }}$ & 54,8 & 22,9 & 14,4 & 8,9 \\
\hline 1 & $44,4 \%$ & 50,1 & 24,4 & 16,3 & 9,2 \\
2 & $49,0 \%$ & 56,1 & 21,5 & 13,2 & 9,2 \\
3 & $55,2 \%$ & 52,3 & 23,1 & 14,9 & 9,7 \\
4 & $50,8 \%$ & & & Atypers outside the frame \\
\hline
\end{tabular}

Source: compiled by the authors

Comparison of students of different courses by the method of generalization of images reveals a $10 \%$ shift: students of 1-2 courses tend to abstract generalization by $10 \%$ more, students of $2-3$ by $10 \%$ more empirical. Abstract and concrete are orthogonal to each other, in addition, "theoretically abstract" is diametrically opposed to "empirically abstract", so that the measurement result indicates a lower level of intellectualization of images in students of 3-4 courses. According to the total difference, the advantage of students of $1-2$ courses is $36 \%$. The results are shown in Table 4, commented in Table 5.

Table 4. Indicators of the Level and Type of Generalization of Perception (in \%)

\begin{tabular}{|c|c|c|c|c|c|c|c|c|c|c|}
\hline \multirow[t]{2}{*}{ Courses } & \multirow{2}{*}{$\begin{array}{c}\text { The } \\
\text { difference } \\
\text { in amounts } \\
\sum_{\text {abstr }}-\Sigma_{\text {emp }}\end{array}$} & \multicolumn{5}{|c|}{ Abstract generalization } & \multicolumn{4}{|c|}{ Empirical generalization } \\
\hline & & $\begin{array}{l}\overline{0} \\
\frac{0}{0} \\
3 \\
\frac{0}{3} \\
\frac{3}{0} \\
0 \\
3\end{array}$ & 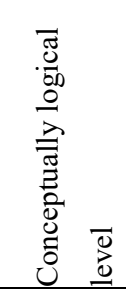 & 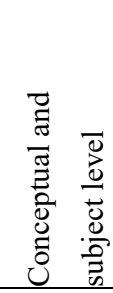 & 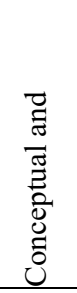 & 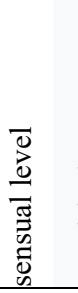 & 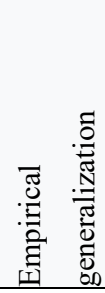 & 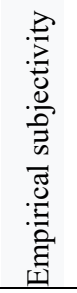 & 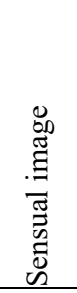 & 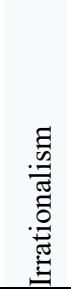 \\
\hline 1 & $-15,0 \%$ & 6,1 & 8,6 & 11,6 & 11,2 & & 12,7 & 14,5 & 15,9 & 9,4 \\
\hline 2 & $-21,6 \%$ & 5,3 & 8,3 & 10,1 & 10,5 & & 10,4 & 15,1 & 20,3 & 10,0 \\
\hline 3 & $-9,6 \%$ & 7,8 & 10,6 & 12,3 & 10,1 & & 12,5 & 11,4 & 16,1 & 9,2 \\
\hline 4 & $-13,6 \%$ & 6,7 & 9,2 & 10,7 & 11,6 & & 14,2 & 12,1 & 16,3 & 9,2 \\
\hline
\end{tabular}

Source: compiled by the authors

Formulation of the idea (topic) of the image:

1) at the poorest level - empirical subjectivity - for students of 3-4 courses $14.5 \%$, and for students of 1-2 courses in the range from $11.4 \%$ to $12.1 \%$. Positions of students of $1-2$ courses are more favorable;

2) but already at the level of empirical Generalization - the results are almost equal;

3) however, at the level of conceptual generalization, students of $1-2$ courses are again ahead by $10-20 \%$ on various indicators. Table 4 shows the correlation analysis.

Table 5. Spearman Correlations: Abstract / Empirical Perception

\begin{tabular}{lccccc}
\hline Courses & $\mathrm{N}$ & Average performance & Abstract & Empirical & $\mathrm{Sr}=$ \\
\hline 1 & $(\mathrm{n}=132)$ & $-15,0 \%$ & $37,5 \%$ & $52,5 \%$ &,$- 713^{* *}$ \\
2 & $(\mathrm{n}=125)$ & $-21,6 \%$ & $34,2 \%$ & $55,8 \%$ &,$- 722^{* *}$ \\
3 & $(\mathrm{n}=654)$ & $-9,6 \%$ & $40,8 \%$ & $49,2 \%$ &,$- 717^{* *}$ \\
4 & $(\mathrm{n}=738)$ & $-13,6 \%$ & $38,2 \%$ & $51,8 \%$ &,$- 710^{* *}$ \\
\hline
\end{tabular}

** Correlations are significant at the level $\mathrm{p} \leqslant 0,01$.

Source: compiled by the authors

The closeness of the statistical relationship between the obtained results is moderately high. The negative correlation reflects the inversely proportional relationship between productivity and counterproductivity.

As a result, the following results were obtained. $37 \%$ of students have a high level of formation of the personal 
component, demonstrate emotional stability, are aware of the importance of the future profession, ready for reflection, capable of adequate self-esteem. $45 \%$ - average level: all the above characteristics are not fully manifested, self-esteem is adequate, but the task for self-development is difficult to set. $18 \%$ - low level: these respondents showed a lack of interest in professional activities, lack of initiative, disorganization. The figure 1 shows that this stage of the study is dominated by the basic level of formation of critical thinking of students. Re-diagnosis was performed taking into account the components of critical thinking by means of the questionnaire "critical analysis" by J. Barrett, the method of finding logical errors of Michael Chaifitz.

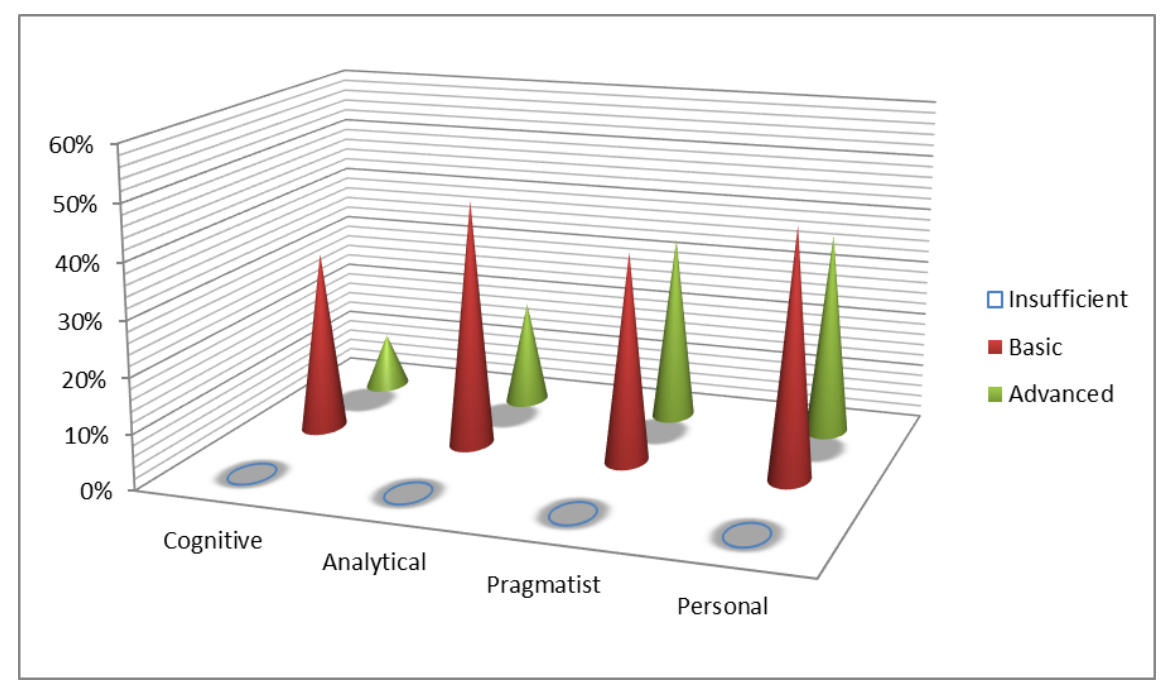

Figure 1. Students' Thinking

Source: Compiled by the Authors

Cognitive component (questionnaire):

- $6 \%$ of students are unfamiliar with the concept of critical thinking. $25 \%$ of students have an idea of this concept, identify several components of critical thinking, but make mistakes in its characterization.

- $69 \%$ of students showed sufficient knowledge of this concept, did not make a mistake in characterizing of critical thinking. Comparative analysis of the results of the ascertaining and repeated stages of the study are presented in Figure 2 .

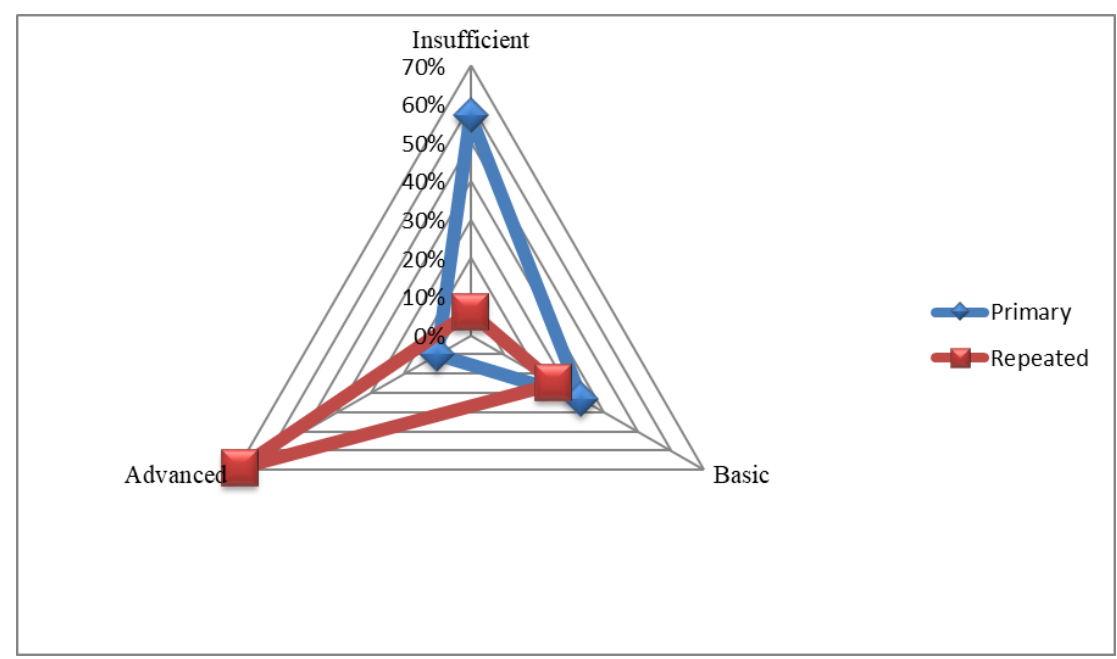

Figure 2. Comparative Analysis of the Results of the Ascertaining and Repeated Stages of Research of the Cognitive Component of Students' Critical Thinking

Source: Compiled by the Authors 
According to the obtained data, the advanced level of formation of the cognitive component of critical thinking increased by $59 \%$, insufficient level was found by $6 \%$ of students, which is $51 \%$ less at the ascertaining stage. Comparative analysis of the results of the development of the analytical component of critical thinking of the ascertaining and repeating stages of the study are presented in Figure 3.

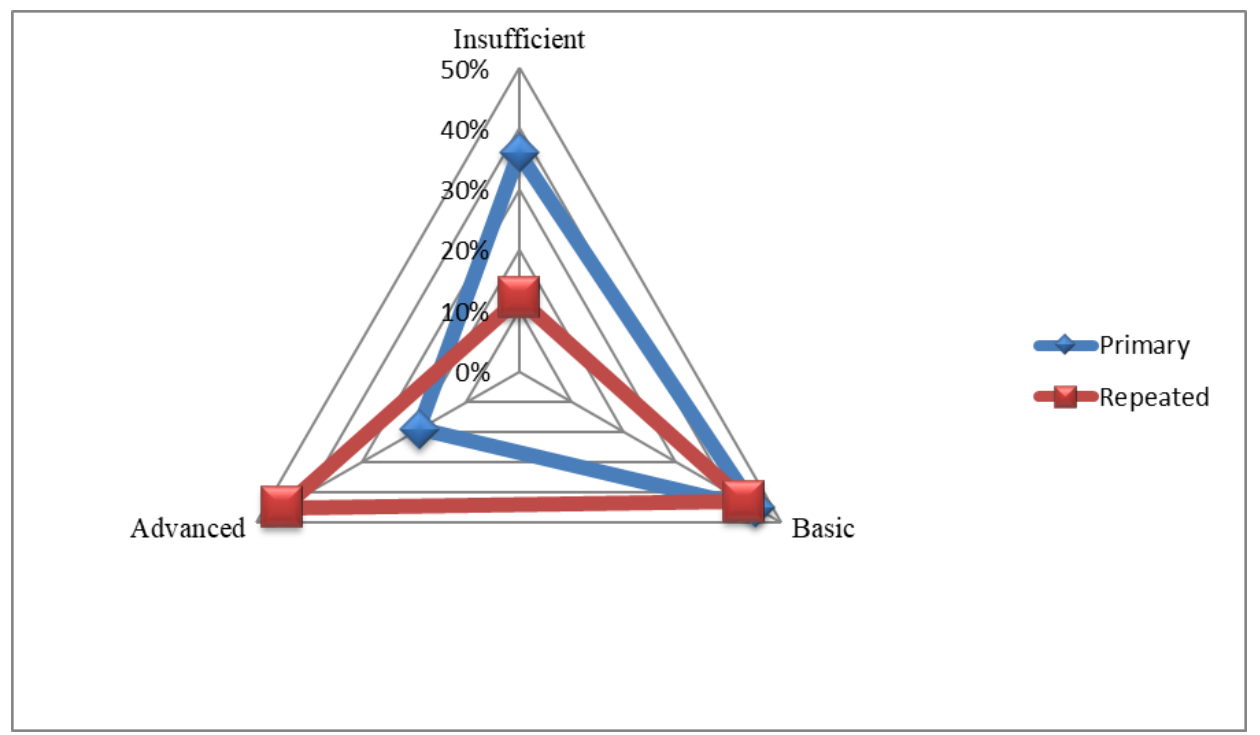

Figure 3. Comparative Analysis of the Results of the Ascertaining and Repeated Stages of Research of the Analytical Component of Critical Thinking of Students

Source: Compiled by the Authors

According to the obtained data, $45 \%$ of students showed an advanced level, which is $26 \%$ more, $14 \%$ of students increased the level of development of the analytical component from insufficient to basic. At the second stage, $12 \%$ of students found an insufficient level.

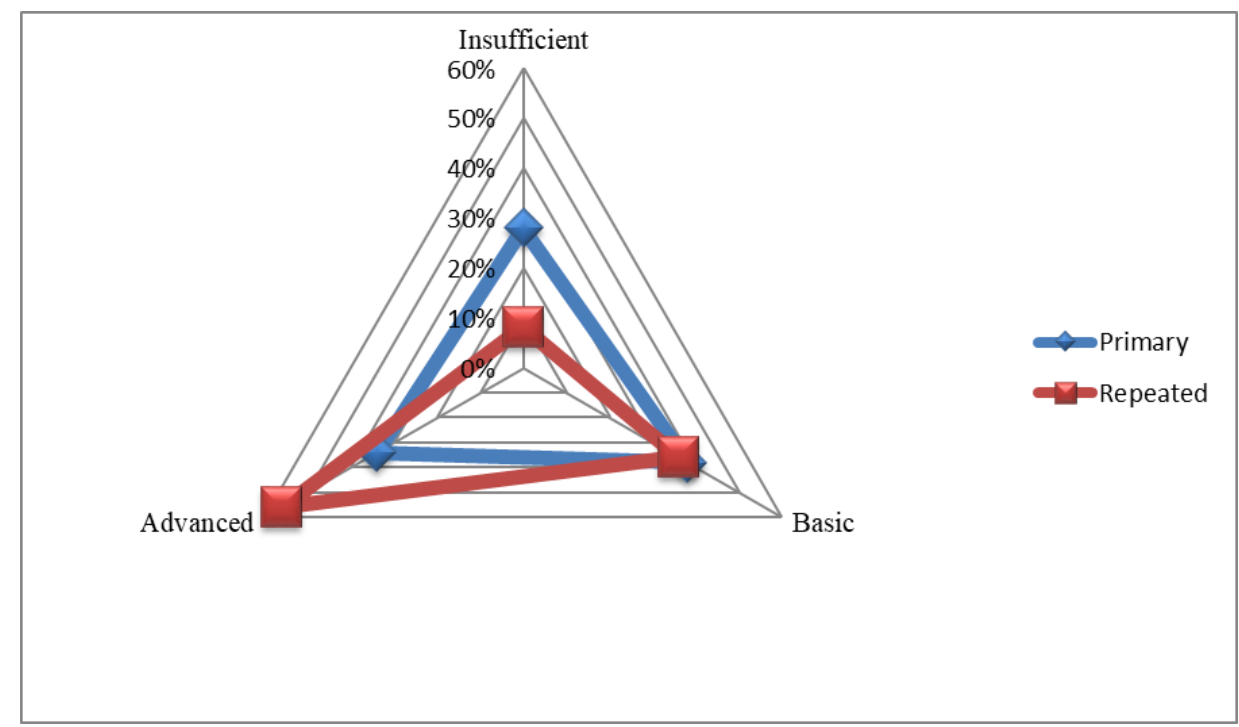

Figure 4. Comparative Analysis of the Results of the Ascertaining and Repeated Stages of Research of the Activity Component of Critical Thinking of Students

Source: Compiled by the Authors 
- activity component (Michael Chaifitz test): low logic and frequent logical errors were demonstrated by $8 \%$ of students, the average norm of logic and inability to catch mistakes in other people's complex judgments were found by $36 \%$ of students, good and high level of logic in reasoning was found by $56 \%$ of students. A comparative analysis of the results of the development of the activity component of critical thinking of the ascertaining and repeated stages of the study are presented in Figure 4.

According to the obtained results, the percentage of students who found an insufficient level decreased to $8 \%$, and $54 \%$ showed an advanced level, which is $20 \%$ more than the ascertaining stage. A comparative analysis of the results of the development of the personal component of critical thinking of the ascertaining and repeated stages of the study is presented in Figure 5.

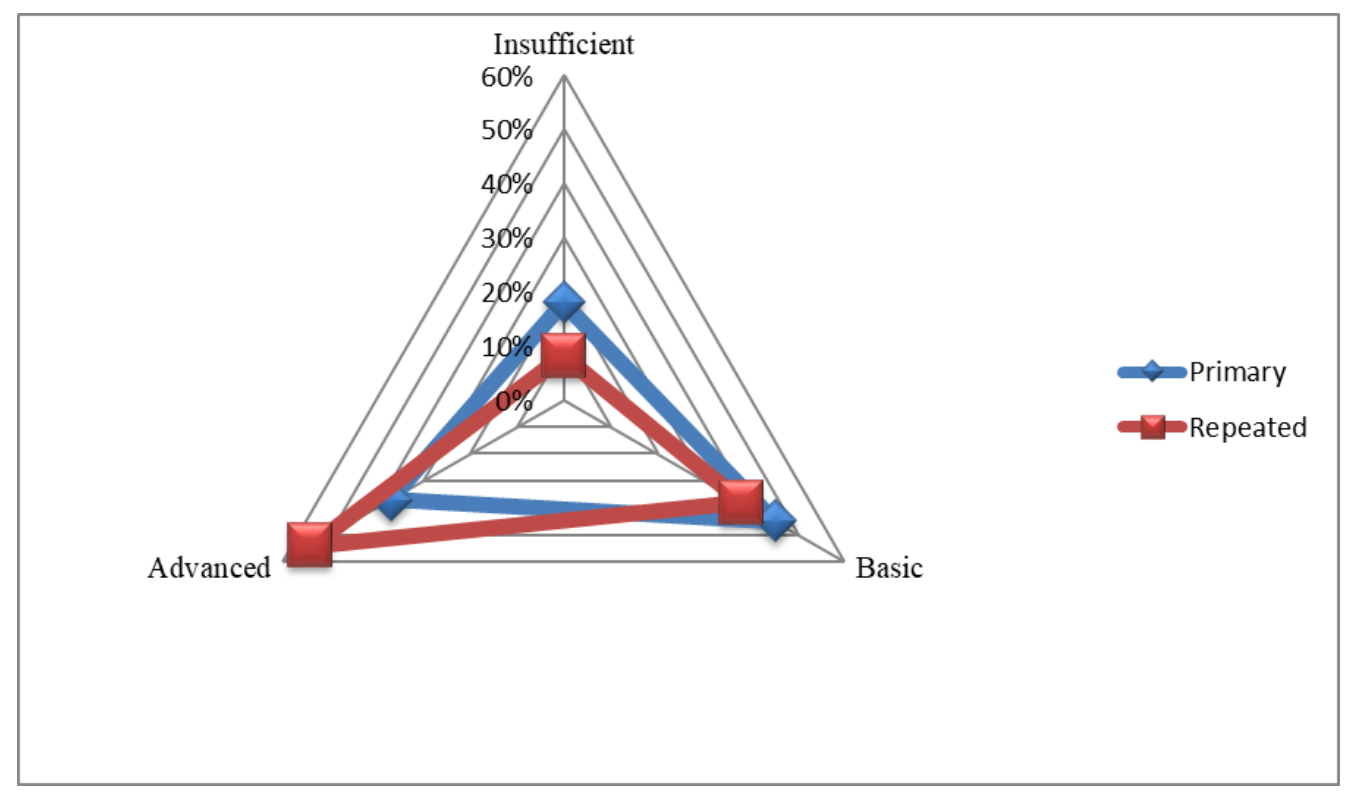

Figure 5. Comparative Analysis of the Results of the Ascertaining and Repeated Stages of Research of the Personal Component of Critical Thinking of Students

Source: Compiled by the Authors

Comparing the results of primary and re-diagnostics, the following was found. Insufficient levels could not be ruled out for any of the components of the development of critical thinking. The students showed the greatest increase in the cognitive component. The analytical component of critical thinking is the most complex, with only $45 \%$ of students showing a willingness to make logical connections and $12 \%$ of students finding it extremely difficult to establish them.

Execution of actions at diagnosing of competences on an example of independent work of students is presented in Table 6.

Thus, the method of Yu. Tatura makes it possible to assess the level of formation of competencies in educational institutions by two components indirectly and approximately. The accuracy of measurement is not essential in this case, as the task of control is to give the teacher indicators to manage the educational process. The qualimetric approach increases the objectification of the assessment of students' learning outcomes. This technique allows for multi-criteria assessment of the formation of competencies, including the educational component of pedagogical activities. The technological approach provides conditions for effective use of this technique in terms of rating control system. 
Table 6. Measuring the Level of Formation of Components of Competence of Independent Work of Students

\begin{tabular}{|c|c|c|c|c|}
\hline $\begin{array}{l}\text { Level of knowledge and } \\
\text { skills }\end{array}$ & Tasks, types of control & Level number & $\begin{array}{l}\text { Quality of } \\
\text { assimilation }\end{array}$ & Mark \\
\hline $\mathrm{C}_{2}$ & $\begin{array}{l}\text { By what indicators are pedagogical } \\
\text { technologies classified? }\end{array}$ & 2 & 4 & 5 \\
\hline$\cdots$ & .. & $\ldots$ & $\ldots$ & $\ldots$ \\
\hline \multicolumn{4}{|c|}{ The sum of points for component C - "knowledge" } & 5 \\
\hline $\mathrm{B}_{3}$ & $\begin{array}{l}\text { Design elements of student learning } \\
\text { technology for the organization of } \\
\text { independent study of the discipline of the } \\
\text { special cycle }\end{array}$ & 3 & 5 & 9 \\
\hline .. & .. & .. & $\ldots$ & $\ldots$ \\
\hline \multicolumn{4}{|c|}{ The sum of points for component B - "skills" } & 9 \\
\hline \multicolumn{4}{|c|}{ Development of the PKK competence potential $=\mathrm{C}+\mathrm{B}$} & 14 \\
\hline \multicolumn{4}{|c|}{ Level of competence formation } & 0,93 \\
\hline
\end{tabular}

Source: compiled by the authors

\section{Discussion}

The study revealed the prerequisites for changing the situation of success in independent work of students in the development of critical thinking. Respondents demonstrate an increase in the level of ability to detect differences in erroneous judgments and build logical inferences based on facts. The most difficult for students is still warning and predicting mistakes; a significant number of students have difficulty solving situations from different points of view. Pochynkova's research (2019) showed the importance of forming students' logical competencies when working independently with complex educational material. The same opinion is expressed in the work of Tynnyi (2021). The authors express the opinion about the decisive role of critical thinking in the process of developing skills for independent education.

The low indicators of the personal component of critical thinking of respondents during independent work should also be noted. Manifestation of such personal qualities as lack of initiative, low motivation, low activity, lack of independence should be the subject of close attention. The article by Suyanto et al. (2019) expresses concern about the ability of students to acquire knowledge through independent work completely. The authors attribute this concern to low motivation to work independently. Instead, the works of Bazhmina (2020) and Zhou (2018) provide data on the high motivation of students to perform tasks for self-study. The authors attribute this concern to low motivation to work independently. In this study, it was not possible to isolate the control and experimental groups. Therefore, the conclusion about the effectiveness of the implemented pedagogical conditions for improving critical thinking is made on the basis of the analysis of the results of the experimental group.

The increase in the level of formation of critical thinking in all its components was facilitated by the conformity of the content, forms, methods and techniques of realization of the pedagogical conditions of the experiment. We are aware of the risks of implementing the formation of students' critical thinking in order to help to improve the success of independent work. These risks are due to the interdisciplinary links and the integrated approach that each discipline focuses on. The risks of forming of critical thinking are noted in the works of Weinberger and Shonfeld (2018) and Kozubovska and Povidaychyk (2021). Researchers have linked their occurrence to low student motivation and high rigidity. However, it should be noted that the intermediate assessment of the level of development of critical thinking of students took place in the process of educational activities, which is realized only in the framework of independent work. For example, in the process of writing reviews and annotations on articles on the theory of teaching and education, compiling an analysis of the teacher, writing reports on the results of pedagogical observation. Similar practical classes are not provided in other general professional disciplines.

The expansion of the share of independent activity of students gives the educational process a practice-oriented and problem-research nature. This is due to the more active involvement of students in the independent implementation of tasks that have an applied focus and a growing level of complexity, uncertainty. Strengthening the importance of VTS in vocational training in the Free Economic Zone, increasing its volume in the structure of curricula and programs involves increase of the responsibility of all participants in the educational process. The responsibility of 
both students and teachers is noted in the study Warsah et al. (2021). The authors note the need for a responsible attitude to the organization of the process of independent work of both students and teachers. The main thing in the strategic line of organization of VTS in the Free Economic Zone is not to optimize its individual types, but to create conditions for high activity. The independence of students in the classroom and outside it in the course of all types of educational activities is one of the main tasks. The same conclusions can be found in the works of Novikov et al. (2021) and Warsah et al. (2019), which indicate the need to motivate students to continuous independent learning activities. In this regard, VTS in a multilevel system of higher education acquires a different meaning in terms of content, time spent, attitude to this activity of both students and teachers. Taking into account the general approaches to the organization of VTS in accordance with the specifics of different free economic zones, the basic principles of designing this activity in professional and pedagogical free economic zones were used in the work.

\section{Conclusions}

The relevance of the study is due to the need to identify and justify the practical use of techniques for the development of critical thinking, which contributes to the development of independent work of students. Independent work is especially important when becoming a professional. That is why higher education differs from general education, first of all, by a higher degree of independence of students. In the modern educational process, there is no problem more important and at the same time more complex than the organization of independent work of the subjects of the educational process in the free educational process. The relevance of the study is due to the need to identify and justify the practical use of techniques for the development of critical thinking, which contributes to the development of independent work of students. Independent work is especially important when becoming a professional. That is why higher education differs from general education, first of all, by a higher degree of independence of students. In the modern educational process, there is no problem more important and at the same time more complex than the organization of independent work of the subjects of the educational process in the free educational process. The importance of this problem is related to the new role of independent work, which it acquires in connection with the transition to the competence paradigm of education. The study found that the average level of rational thinking in all groups of respondents there is at the average level and is approximately $50 \%$. Students of 1-2 courses have $10 \%$ more attraction to abstract generalization, students of $2-3$ are by $10 \%$ more empirical. Empirical subject matter is for students of 3-4 courses $14.5 \%$, and for students of $1-2$ courses from $11.4 \%$ to $12.1 \%$. The research has practical and theoretical significance. At the practical level, the study can be used by all those interested in improving the quality of independent work of students. At the theoretical level, the work will be of interest to researchers studying the development of critical thinking and its impact on the learning process. Further research can be organized in the direction of developing and implementing the development of critical thinking to improve the acquisition of competencies, taking into account future professional activities.

\section{References}

Akramova, G. R., \& Akramova, S. R. (2021). Pedagogical and psychological conditions of preparing students for social relations on the basis of the development of critical thinking. Psychology and Education Journal, 58(2), 4889-4902. https://doi.org/10.17762/pae.v58i2.2886

Anugraheni, I. (2017). Penggunaan Portofolio dalam Perkuliahan Penilaian Pembelajaran. Jurnal Pendidikan Dasar Perkhasa, 3(1), 246-258.

Bazhmina, Ye. (2020). Use of BYOD technologies in the educational process. Scientific notes of Berdyansk State Pedagogical University, 3, 27-40.

Hampton, D., \& Keys, Y. (2017). Generation Z students: Will they change our nursing classrooms? Journal of Nursing Education and Practice, 7(4), 111-115. https://doi.org/10.5430/jnep.v7n4p111

Kobzyeva, I. (2021). Psychological and pedagogical analysis of the problem of forming critical thinking in applicants for higher education. Proceedings of the Second All-Ukrainian Scientific and Practical Conference with International Participation "Current Issues of Social and Humanitarian Secondary and Higher Education", 104-109.

Retrieved

from

http://dano.dp.ua/attachments/article/392/Актуальні\%20питання\%20соціально-гуманітарної\%20середньої\% 20та\%20вищої\%20освіти\%20-\%202021.pdf\#page=104

Kozubovska, I. V., \& Povidaychyk, M. M. (2021). Formation of critical thinking of future masters in the process of professional training: foreign experience. Current trends in the development of science and practice. The XVII 
International Science Conference "Current trends in the development of science and practice», 134-136. Retrieved http://ir.librarynmu.com/bitstream/123456789/2378/1/XVII-Conference-Current-trends-in-the-development-of-s cience-and-practice.pdf\#page $=135$

Kusumawati, R., Hobri, H., \& Hadi, A. F. (2019). Implementation of integrated inquiry collaborative learning based on the lesson study for learning community to improve students' creative thinking skill. Journal of Physics: Conference Series, 1-11. https://doi.org/10.1088/1742-6596/1211/1/012097

$\mathrm{Li}$, L. (2016). Integrating thinking skills in foreign language learning: What can we learn from teachers' perspectives. Thinking Skills and Creativity, 22, 273-288.

Marshall, A. L., \& Wolanskyj-Spinner, A. (2020). COVID-19: Challenges and opportunities for educators and $\begin{array}{llllll}\text { generation } Z \text { learners. Mayo Clinic Proceedings, } & \text { 95(6), }\end{array}$ https://doi.org/10.1016/j.mayocp.2020.04.015

Marynchenko, H., \& Motsak, S. (2021). Formation of critical thinking of students during distance learning. The Grail of Science, 4, 463-467. https://doi.org/10.36074/grail-of-science.07.05.2021.083

Novikov, V. M., Tkachenko, P. I., Rezvina, K. Yu., Khattu, V. V., \& Popelo, Yu. V. (2021). Technologies of critical thinking in high school. Realities, problems and prospects of higher medical education: materials of educational and scientific conference with international participation, 191-193. Retrieved from http://elibumsa.pl.ua/bitstream/umsa/16051/1/Novikov_Tehnologii_kritichnogo_mislennya.pdf

Osadchyy, I. H. (2015). Vectors of modernization of the institution of postgraduate pedagogical education in the spheres of educational, scientific and methodical support of activity and innovative development of the education system of the region. Director of school, lyceum, gymnasium, 6, 6-17.

Panasiuk, O., Akimova, L., Kuznietsova, O., \& Panasiuk, I. (2021). Virtual Laboratories for Engineering Education. Proceedings of the 11th International Conference on Advanced Computer Information Technologies: ACIT 2021 (pp. 637-641). Deggendorf: IEEE.

Pochynkova, M. M. (2019). Definition of "critical thinking" in scientific pedagogical discourse. Education and Pedagogical Sciences, 1(170), 25-37.

Proshkin, V., Astafieva, M., \& Radchenko, S. (2018). Formation of critical thinking of future teachers of mathematics by means of geometry. Educational discourse, 100-115. https://doi.org/10.28925/2312-5829.2018.1-2.1416

Riany, Y. E., Haslam, D., Musyafak, N., Farida, J., Ma, S., \& Sanders, M. (2018). Understanding the role of parenting in developing radical beliefs: Lessons learned from Indonesia. Security Journal, 32(3), 236-263. https://doi.org/10.1057/s41284-018-00162-6

Romanova, E. N. (2021). Motivating critical thinking in students by means of foreign language. International Research Journal, 5(107), 132-134.

Savchenko, S., \& Kurylo, V. (2019). Formation of Critical Thinking as One of the Conditions for Successful Socialization of the Modern Personality. Bulletin of Taras Shevchenko Luhansk National University. Pedagogical sciences, 6(329), 64-71. https://doi.org/10.12958/2227-2844-2019-6(329)-1-64-71

Schmitt, C. A., \& Lancaster, R. J. (2019). Readiness to practice in Generation Z nursing students. Journal of Nursing Education, 58(10), 604-606. https://doi.org/10.3928/01484834-20190923-09

Seemiller, C., \& Grace, M. (2017). Generation Z: Educating and engaging the next generation of students. About Campus, 22(3), 21-26. https://doi.org/10.1002/abc.21293

Shah, N., \& Lewis, C. M. (2019). Amplifying and Attenuating Inequity in Collaborative Learning: Toward an $\begin{array}{lllll}\text { Analytical } & \text { Framework. }\end{array}$ https://doi.org/10.1080/07370008.2019.1631825

Sujito, W., Kurniasih, N., Bakri, S., Budi Santosa, R., Hasan, M., \& Istiqomah, L. (2019). Combining subtext application technology and collaborative writing to improve EFL remedial students' writing competence with different learning style. Journal of Physics: Conference Series, 1175(1). https://doi.org/10.1088/1742$6596 / 1175 / 1 / 012230$

Sulisworo, D., \& Syarif, F. (2018). The Utilization of Open Educational Resources in the Collaborative Learning 
Environment to Enhance the Critical Thinking Skill. International Journal of Learning and Development, 8(1), 73. https://doi.org/10.5296/ijld.v8i1.12399

Suyanto, B., Sirry, M., \& Sugihartati, R. (2019). Pseudo-radicalism and the deradicalization of educated youth in Indonesia. Studies in Conflict and Terrorism, 1-20. https://doi.org/10.1080/1057610X.2019.1654726

Tynnyi, V. I. (2021). Information technology in the context of developing critical thinking through foreign language learning. International Scientific and Practical Conference. Seoul, South Korea, 2(11), 39-41. https://doi.org/10.36074/logos-30.04.2021.v2.11

Volet, S., Seghezzi, C., \& Ritchie, S. (2019). Positive emotions in student-led collaborative science activities: relating types and sources of emotions to engagement in learning. Studies in Higher Education, 44(10), 1-13. https://doi.org/10.1080/03075079.2019.1665314

Warsah, I., Masduki, Y., Daheri, M., \& Morganna, R. (2019). Muslim Minority in Yogyakarta: Between Social Relationship and Religious Motivation. Qudus International Journal of Islamic Studies, 7(2), 1-32. https://doi.org/10.21043/qijis.v7i2.6873

Warsah, I., Morganna, R., Uyun, M., Hamengkubuwono, H., \& Afandi, M. (2021). The Impact of Collaborative Learning on Learners' Critical Thinking Skills. International Journal of Instruction, 14(2), 443-460. https://doi.org/10.29333/iji.2021.14225a

Weinberger, Y., \& Shonfeld, M. (2018). Students' willingness to practice collaborative learning. Teaching Education, 31(11), 1-17. https://doi.org/10.1080/10476210.2018.1508280

Witriyahati, S., Yayah Haenilah, E., \& Rochmiyati, H. (2021). Development of problem based learning (PBL) model on thematic learning to increase critical thinking ability in class v elementary school students. Social Science Learning Education Journal, 6(8), 12-21.

Zhou, Z. (2018). An empirical study on the influence of PBL teaching model on college students' critical thinking ability. English Language Teaching, 11(4), 15-20. https://doi.org/10.5539/elt.v11n4p15 


\section{APPENDIX A}

TAXONOMIC TABLE OF DIAGNOSTIC METHODS Y. TATURA

\begin{tabular}{|c|c|}
\hline $\begin{array}{l}\text { Number } \\
\text { and level } \\
\text { index }\end{array}$ & LEVEL OF COMPONENT DEVELOPMENT \\
\hline \multicolumn{2}{|r|}{ Gnostic component of competencies } \\
\hline 1. $C_{1}$ & $\begin{array}{l}\text { Recognition of studied objects, properties, processes; idea of their belonging to a certain area of reality } \\
\text { (knowledge - orientation) }\end{array}$ \\
\hline 2. $\mathrm{C}_{2}$ & $\begin{array}{l}\text { Self-reproduction of the studied material from memory in written or oral forms; demonstration of } \\
\text { understanding of the meaning of reproducible knowledge (knowledge - copies) }\end{array}$ \\
\hline 3. $\mathrm{C}_{3}$ & $\begin{array}{l}\text { Reproduction and understanding of the received knowledge; the ability to present them in the form of } \\
\text { logically complete elements, to indicate the commonality and difference of the studied methods, } \\
\text { techniques, methods (analytical knowledge) }\end{array}$ \\
\hline 4. $\mathrm{C}_{4}$ & $\begin{array}{l}\text { Reproduction and understanding of the received knowledge; ability to analyze them, assess the } \\
\text { connection with related areas of knowledge; to determine the applicability of concepts, laws, etc. } \\
\text { (system knowledge) }\end{array}$ \\
\hline \multicolumn{2}{|r|}{ Functional component of competencies } \\
\hline 1. $\mathrm{B}_{1}$ & Ability to perform actions based on instructions in a known situation (primary skills) \\
\hline 2. $\mathrm{B}_{2}$ & $\begin{array}{l}\text { Ability to perform independently typical actions that require a choice of methods from among those } \\
\text { known in the expected situation (reproductive skills) }\end{array}$ \\
\hline 3. $\mathrm{B}_{3}$ & $\begin{array}{l}\text { Ability to perform actions related to solving non-standard tasks, which provide a variety of solutions } \\
\text { that require a choice of methods (productive actions) }\end{array}$ \\
\hline 4. $\mathrm{B}_{4}$ & $\begin{array}{l}\text { Ability to perform actions related to solving research tasks, involving the acquisition of new } \\
\text { knowledge, requiring the development of innovative approaches and methods of solution (research } \\
\text { skills) }\end{array}$ \\
\hline \multicolumn{2}{|r|}{ Value-aesthetic component of competencies } \\
\hline 1. $\mathrm{O}_{1}$ & $\begin{array}{l}\text { Demonstration of indifference to education and work in a particular area, lack of desire to perform the } \\
\text { assigned work without additional incentive; the desire to abdicate responsibility for the work } \\
\text { performed }\end{array}$ \\
\hline 2. $\mathrm{O}_{2}$ & $\begin{array}{l}\text { Demonstration of a positive attitude to education and work; showing responsibility and initiative, } \\
\text { especially in conditions of additional motivation }\end{array}$ \\
\hline 3. $\mathrm{O}_{3}$ & $\begin{array}{l}\text { Demonstration of persistence and enthusiasm in mastering their profession, demonstration of } \\
\text { creativity; willingness to make decisions independently, to be responsible for their activities }\end{array}$ \\
\hline
\end{tabular}

\section{Copyrights}

Copyright for this article is retained by the author(s), with first publication rights granted to the journal.

This is an open-access article distributed under the terms and conditions of the Creative Commons Attribution license (http://creativecommons.org/licenses/by/4.0/). 